
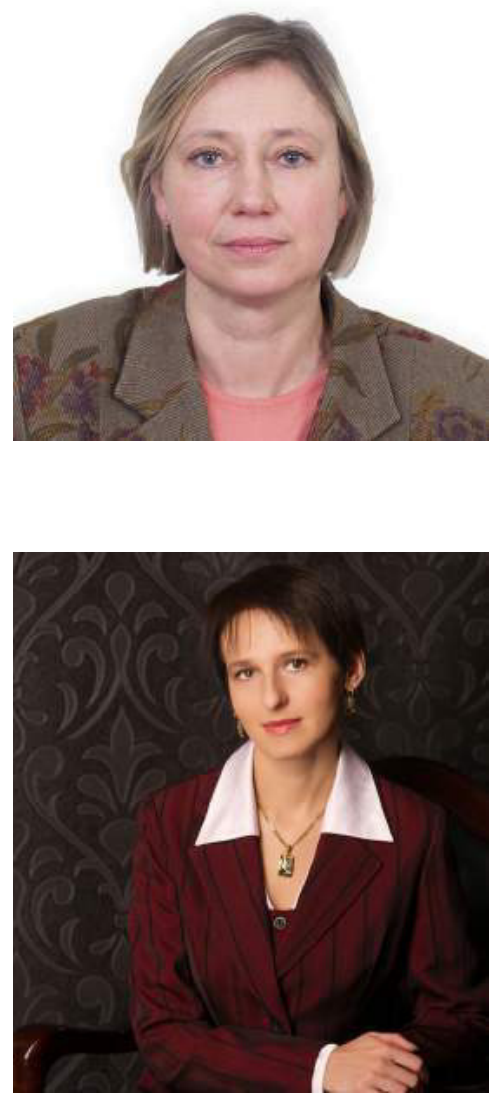

\section{Наталія Голуб,}

кандидат педагогічних наук, доцент, Харківський національний педагогічний університет імені Г. С. Сковороди

(м. Харків)

\section{Nataliya Golub,}

Candidate of Pedagogical Sciences, Associate Professor, Kharkiv G. S. Skovoroda National Pedagogical University (Kharkiv) nataly.golub@ukr.net

ID orcid.org/0000-0003-0777-6074

\section{Вікторія Перлова,}

кандидат педагогічних наук, доцент,

Харківський національний педагогічний університет

імені Г. С. Сковороди

(м. Харків)

\section{Victoria Perlova,}

Candidate of Pedagogical Sciences, Associate Professor, Kharkiv G. S. Skovoroda National Pedagogical University (Kharkiv) educationandsciencetoday@gmail.com

ID orcid.org/0000-0002-0522-2871

\title{
ПЕРЕДУМОВИ ТА ПОКАЗНИКИ ГОТОВНОСТІ ДИТИНИ ДО ВИВЧЕННЯ РІДНОÏ ТА ІНОЗЕМНОї МОВ У ПОЧАТКОВІЙ ШКОЛІ
}

\section{PRECONDITIONS AND INDICES OF CHILD'S READINESS TO LEARN THE NATIVE AND FOREIGN LANGUAGES IN PRIMARY SCHOOL}

У статті розглядаються передумови та показники готовності дитини до опанування писемною формою української (рідної) мови та вивчення нею іноземної мови. Актуальність проблеми пов'язана із зростанням чисельності дітей, які мають стійкі труднощі в оволодінні зазначеними предметами шкільної програми. Авторами акцентується увага на тих уміннях і навичках, які у своєму комплексі мають свідчити про готовність дитини до оволодіння предметами мовного циклу. Така готовність включає повноцінний розвиток імпресивної та експресивної сторін рідного мовлення дитини, а також достатню сформованість у неї цілої низки невербальних функцій (моторики, гнозису, праксису, пам'яті, мислення) й відповідну мотивацію до навчання.

Ключові слова: початкова школа, готовність до опанування навичками читання та письма, вивчення рідної та іноземної мов.

The aim of the article is analysis of preconditions and indices of child's readiness to master the written form of the Ukrainian language (the native language) and to learn the foreign language. The topicality of the problem can be explained by the increasing number of children who have stable difficulties in learning languages at school. The authors draw attention to those skills and subskills the formation of which can serve as evidence of child's readiness to have a good command of the native and foreign languages. This readiness includes full-fledged development of impressive and expressive aspects of the child's native speech. The article represents normative indices of the level of formation of phonetic, lexical and grammatical systems. A child is supposed to use phonetic, lexical and grammatical language generalizations formed in preschool period as basis for mastering reading and writing skills in the native language and learning the foreign language. An ability to acquire certain language generalizations forms learner's language competence that is necessary for formation of mental structures of language units and regulations of their functioning both on the practical and theoretical levels. The sufficient level of formation of child's fine motor skills, gnosis, praxis, mnestic and mental functions as well as motivation for learning provide successful development of reading and writing skills both in the native and in the foreign languages. 
Considering the fact that stable and specific errors in the process of reading and writing are often connected with drawbacks of oral speech and partial shortage of development of learners' non-verbal functions the authors draw attention to the set of preventive measures used for working with children before they start attending school.

Keywords: primary school, readiness for mastering reading and writing skills, learning the native and foreign languages.

В статье рассматриваются предпосылки и показатели готовности ребенка к овладению письменной формой украинского (родного) языка и изучения им иностранного языка. Актуальность проблемы связана с ростом численности детей, которые имеют стойкие трудности в овладении указанными предметами школьной программы. Авторами акцентируется внимание на тех умениях и навыках, которые в своем комплексе должны свидетельствовать о готовности ребенка к овладению предметами языкового цикла. Такая готовность включает полноценное развитие импрессивной и экспрессивной сторон родной речи ребенка, а также достаточную сформированность у него целого ряда невербальных функций (моторики, гнозиса, праксиса, памяти, мышления) и соответствующую мотивацию к учебной деятельности.

Ключевые слова: начальная школа, готовность к овладению навыками чтения и письма, изучение родного и иностранного языков.

Постановка проблеми в загальному вигляді та її зв'язок з важливими науковими та практичними завданнями. Успішність засвоєння дитиною шкільної програми, яка поряд із базовими навчальними предметами включає також і вивчення іноземної мови, безпосередньо залежить від ї̈ готовності до процесу навчання у школі. Ризик виникнення стійких труднощів у навчанні молодших школярів часто пов'язаний із парціальною несформованістю в них цілої низки психічних функцій. Для таких дітей нерідко характерні: недоліки мовлення, низька пізнавальна активність, швидка розумова втомлюваність, зниження об'єму уваги та пам'яті, моторна незграбність, недостатня сформованість умінь планувати, регулювати, контролювати свою діяльність (Е. Данілавічютє, В. Ільяна, О. Корнєв, Р. Лалаєва, І. Мартиненко, В. Тарасун, Н. Чередніченко, М. Шеремет та ін.). Указана проблема акцентує увагу на питаннях своєчасної діагностики тих особливостей у розвитку дитини, які можуть обумовлювати її низьку успішність у навчанні, зокрема при опануванні писемною формою рідної мови та при вивченні іноземної мови.

Аналіз останніх досліджень і публікацій, у яких започатковано розв'язання проблеми. Найважливішими складовими готовності дитини до навчання у школі є сформованість у неї соціально-комунікативних умінь, достатній розвиток сенсомоторних, мнестичних функцій, наочного та основ словесно-логічного мислення, а також певний рівень особистісного розвитку, у якому особливого значення набуває мотиваційний фактор, що включає пізнавальні та соціальні мотиви навчання, достатній розвиток довільності поведінки (Ш. Амонашвілі, Б. Ананьєв, Л. Артемова, А. Богуш, Л. Божович, В. Бондар, Р. Буре, І. Вашуленко, Л. Венгер, Л. Виготський, Д. Ельконін, Я. Йєрасик, О. Запорожець, І. Зимня, Н. Зубалій, Л. Калмикова, З. Кличнікова, С. Коробко, В. Котирло, К. Крутій, С. Ладивір, В. Мухіна, О. Проскура, О. Савченко, І. Шванцара та ін.).

Формування мети статті. Метою статті $€$ визначення передумов та показників готовності дитини до успішного опанування рідною та іноземною мовами за програмою початкової школи.

Виклад основного матеріалу дослідження з повним обґрунтуванням отриманих наукових результатів. Виключно важливим у процесі оволодіння дитиною читанням та письмом українською (рідною) мовою, а також опанування іноземною мовою, є ї̈ опора на ті мовні узагальнення, що сформувалися в неї під час опанування рідним мовленням у дошкільний період. 3 цього приводу можна говорити про мовні здібності, на основі яких у школі буде формуватися мовна компетентність учня.

Мовні здібності включають складну сукупність умінь і навичок, стратегій, схем дій, знань та уявлень про мовні одиниці й мовні правила. Їхній характер визначають як біологічні, так і соціальні фактори.

До біологічних факторів ми маємо відносити: стать дитини; стан її мозкових структур, особливості їхнього функціонування і послідовність дозрівання у ході онтогенезу, тип функціональної міжпівкулевої асиметрії; індивідуальні особливості характеру та пізнавальної діяльності. Індивідуально-типологічні розбіжності під час засвоєння дітьми різних боків мовленнєвої та мовної систем відмічаються у дослідженнях В. Артемова, В. Бельтюкова, Б. Бєляєва, О. Гвоздєва, С. Жуйкова, І. Зимньої, Г. Костюка, В. Макарової, А. Маркової, О. Скрипченко, В. Тарасун, С. Цейтлін та ін.

У сучасних умовах слід зважати на проблему збільшення кількості дітей, які стикаються із значними утрудненнями під час навчання у школі. Така тенденція найбільшою мірою пов'язана із погіршенням здоров'я дитячого населення. Доволі часто причиною шкільних труднощів виступають порушення функціонування нервової системи. Ці розлади часто не мають тяжкого характеру, однак вони знижують адаптивні ресурси ЦНС й утруднюють оволодіння дітьми шкільними уміннями та навичками (Т. Ахутіна, Л. Бадалян, О. Балашова, М. Безрукіх, В. Ковальов, О. Корнєв, Н. Корсакова, Н. Куінджи, Р. Лалаєва, О. Мастюкова, Ю. Мікадзе та ін.).

Серед соціальних факторів ключовим $€$ мовне середовище зі всією сукупністю мовної продукції, яку сприймає дитина. Чим багатшим є мовне середовище, тим більше у дитини можливостей щодо засвоєння мовних одиниць, правил їх конструювання і використання під час спілкування з оточуючими (А. Богуш, Дж. Брунер, Л. Виготський, Д. Ельконін, О. Запорожець, О. О. Леонтьєв, Ж. Піаже, Д. Слобін, Т. Ушакова, С. Цейтлін, О. Шахнарович та ін.). Треба відмітити те, що у сучасних умовах доволі часто спостерігаються випадки соціально-педагогічної занедбаності дитини, дефіциту спілкування у родині та інші негативні соціальні фактори, які посилюють дію несприятливих біологічних чинників у виникненні стійкої шкільної неуспішності учня. 
Формування мовних здібностей відбувається в тісному зв'язку з процесами аналізу, переробки й збереження знань про мову, з їхнім узагальненням і організацією у складну та злагоджену систему. Відповідно, із мовними здібностями особистості найбільшою мірою корелює її успішність в опануванні різними формами мовленнєвої і комунікативної діяльності при засвоєнні рідної та іноземної мов.

Мовна компетентність індивіда пов'язана із засвоєнням (у дошкільному віці на практичному, а з початком навчання у школі на теоретичному рівні) структури мовних одиниць і закономірностей їх функціонування, спроможністю розв'язувати певні лінгвістичні завдання. У дитини молодшого шкільного віку мовна компетентність $€$ системою практичних і початкових теоретичних знань про звукову, лексичну, граматичну будову мови, які дозволяють породжувати й розуміти різні типи мовленнєвих висловлювань (О. О. Леонтьєв, О. Савченко, Є. Соботович, В. Тарасун та ін.).

Отже, навчання молодшого школяра писемної форми рідної мови, усної і писемної форм іноземної мови має спиратися на наявні у нього фонетико-фонематичні, лексико-граматичні узагальнення, що сформувалися при опануванні українським (рідним для дитини) мовленням ще на етапі дошкільного дитинства.

Що стосується фонетико-фонематичної сторони мовлення, то успішність засвоєння дитиною звукового складу слів, точний вибір звуку при відтворенні мовленнєвого матеріалу визначається рівнем сформованості в неї диференційної фонематичної чутливості та розвитком артикуляційної моторики. Дитина має чітко виділяти фонеми, впізнавати їх за тими інваріантними, змісторозрізнювальними ознаками, за якими одна фонема протиставлена іншим, що потребує засвоєння фонологічних диференційних ознак спочатку рідної, а потім іноземної мови (Л. Бондарко, Д. Ельконін, Л. Зіндер, Ф. Сохін, М. Швачкін, Л. Щерба та ін.). Достатньо розвинений фонематичний слух і тонкодиференційовані рухи органів артикуляції забезпечують нормоване вимовляння дитиною звуків рідного мовлення, що стає однією з важливих передумов успішного оволодіння технічною стороною писемної форми рідної мови та звуко-буквеною системою іноземної мови.

Отже, на момент вступу до школи необхідними $€$ сформованість у дитини правильної звуковимови і фонологічних узагальнень на практичному рівні. На цій підставі до групи осіб із підвищеним ризиком виникнення в них порушень писемного мовлення слід відносити дітей із: вадами звуковимови (заміни і змішування звуків); порушеннями диференціації звуків на слух; порушеннями звукової та складової структури слів (пропуски, перестановки звуків, складів). Особливої уваги потребують не скільки антропофонічні, скільки фонологічні дефекти. При змішуваннях і замінах звуків, як фонологічних дефектах, порушуються звукові протиставлення, тому найбільшою мірою виявляється нестабільність звукової системи мови (Р. Лалаєва, Є. Соботович, В. Тарасун, Г. Чиркіна, М. Шеремет та ін.).

Щодо лексичних узагальнень, то функціональні утворення, які пов'язані із засвоєнням слів, взагалі, є основними (базовими) елементами внутрішньомовленнєвих механізмів, на основі яких організовані всі інші процеси.

Розвиток семантики мовлення тісно пов'язаний із розвитком мислення, оскільки засвоєння мовних засобів відбувається шляхом узагальнення та категоризації предметів і явищ навколишнього світу, одиниць і закономірностей мовної дійсності. Із засвоєнням категоріальної співвіднесеності слів відбувається структуризація семантичних полів, здійснюється розвиток лексичної системності, формуються словесні поняття з різним ступенем інтеграції (Н. Арутюнова, Л. Виготський, О.О. Леонтьєв, О. Лурія, Є. Соботович, Т. Ушакова, О. Шахнарович та ін.).

Як указує Л. Виготський [1], залежно від того, якого ступеню досягла дитина у розвитку значення своїх слів, на такому ж знаходяться всі основні системи її психічних функцій. Дитина, яка приходить до школи, має користуватися словами узагальнювального характеру, співставляти конкретні (видові) і доступні їй родові поняття, використовувати антоніми, окремі синоніми. Важливою є її спроможність диференціювати слова, що $є$ близькими за своїм значенням, правильно сприймати багатозначне слово у різних контекстах.

Що стосується граматичного ладу мовлення, то на момент вступу до школи здорова дитина на практичному рівні опановує основними граматичними категоріями. Граматичні значення завжди більш абстрактні, ніж лексичні, а граматична система мовлення організована на основі більшої кількості мовних правил. На момент вступу до школи дитина має орієнтуватися на власне граматичні ознаки мови, правильно обирати граматичні форми слів, спиратися на граматичні значення морфем слова, оперувати ними, крім цього, в неї має бути достатній арсенал синтаксичних конструкцій, якими вона користуватиметься під час побудови висловлення (А. Богуш, О. Гвоздєв, К. Крутій, Д. Слобін, Ф. Сохін, Т. Ушакова, О. Шахнарович, С. Цейтлін та ін.).

Ще одним важливим показником $є$ рівень сформованості в дитини зв'язного мовлення. У нормі дитина, яка приходить до школи, спроможна доволі розгорнуто, послідовно, точно і правильно передати певний зміст доступного їй за віком повідомлення (А. Богуш, А. Бородич, М. Кольцова, Г. Ляміна, Т. Піроженко, Ф. Сохін, Є. Тихєєва та ін.).

Отже, засвоєння учнем у школі писемної форми рідної мови та вивчення іноземної мови будуватиметься на основі достатньо розвиненого рідного мовлення. Характеризуючи стан усної форми рідного мовлення дитини на момент вступу її до школи, доцільно зважати на рівень сформованості імпресивної та експресивної його сторін, зокрема:

1. Умінь і навичок, що забезпечують процес сприймання та розуміння мовлення: 
- спроможність впізнавати та розуміти слова відповідно до їх значення, розрізняти за значенням слова, що є схожими за звучанням;

- розуміти предметно-змістову сторону висловлення;

- орієнтуватися на інтонаційну сторону висловлення, що сприяє розумінню мети повідомлення;

2. Умінь і навичок, що забезпечують процес побудови висловлення:

- програмувати і передавати певний задум (думку, бажання та ін.);

- добирати для висловлення слова відповідного лексичного і граматичного значення;

• правильно відтворювати звуко-складову структуру слів;

- правильно будувати прості синтаксичні конструкції;

- використовувати різноманітні види висловлювань відповідно до комунікативного завдання.

3. Уміння відрізняти правильно оформлені висловлення від неправильно (помилково) оформлених (як у чужому, так і у власному мовленні), визначати й виправляти почуті помилки.

4. Уміння здійснювати елементарні форми мовного аналізу та синтезу (фонематичного, складового, поділу речення на слова, складання речення зі слів).

Що стосується спроможності дитини опановувати навичками читання та письма як рідної, так і іноземної мов, то для цього необхідним є також достатній рівень сформованості в неї дрібної моторики, гнозису, праксису, мнестичних і мисленнєвих функцій.

Важливою для розвитку письма є сформованість тонкої диференційованої моторики пальців рук (Н. Бернштейн, Г. Галкіна, Е. Гур'янов, Т. Дубініна, В. Дудьєв, Д. Ельконін, О. Запорожець, М. Кольцова, Я. Неверович та ін.). Правильне та усталене переведення оптичних образів букв у графічні накреслення за допомогою рухів руки є результатом сформованості відповідних графо-моторних навичок, на успішність засвоєння яких впливає розвиненість зорово-моторної координації, кінестетичного та кінетичного праксису.

Виключно важливими для навчання у школі є достатньо розвинені в дитини слуховий гнозис та фонематичні процеси. Щодо розвитку зорових функцій, то у здорової дитини на момент вступу до школи достатньо сформованими мають бути зорове та зорово-просторове сприймання та відповідні уявлення, зоровий аналіз і синтез, вміння орієнтуватися у просторі; до того ж дитина має володіти основними поняттями, що відображають просторові параметри об’єктів, їх розташування (Б. Ананьєв, Т. Ахутіна, П. Горфункель, О. Запорожець, Л. Переслені, Л. Рожкова, А. Семенович, Д. Фарбер, Л. Цвєткова, Є. Хомська та ін.).

Для засвоєння писемної форми рідної мови й опанування іноземною мовою у молодшого школяра мають бути достатньо розвинені пам'ять і мислення. Стосовно розвитку мнестичної та мисленнєвої діяльності слід зазначити, що у нормі на момент вступу до школи дитина вже здатна до оволодіння різноманітними складними формами навчально-пізнавальної діяльності, про що свідчить «дозрівання» її нервової системи: збільшується активність асоціативних, найбільш складних за своєю організацією ділянок мозку, стає чітко вираженою асиметрія діяльності великих півкуль, відбувається перебудова морфофункціональних зв'язків кори. Дитина здатна засвоювати достатньо значну за обсягом і складністю інформацію. Активізація пізнавальної діяльності пов'язана зі спроможністю дитини даного віку цілеспрямовано та достатньо тривало спостерігати за предметами і явищами (може уважно слухати та щось розглядати), значно зростають її можливості щодо розумової діяльності: вона здатна порівнювати, виявляти суттєве, робити узагальнення, визначати послідовність розумових операцій тощо.

Отже, на момент вступу до школи дитина має досягти шкільної зрілості. Під «шкільною зрілістю» слід розуміти такий рівень фізичного, психічного, у тому числі розумового й мовленнєвого розвитку дитини, який дозволяє залучати ї̈ до систематичного навчання, нового режиму життя, різного роду навантажень, які не будуть для неї занадто виснажливими (Л. Божович, Г. Бориско, Л. Венгер, С. Громбах, Г. Даниленко, Д. Ельконін, О. Запорожець, Я. Йєрасик, А. Керн, С. Конова, Н. Куінджи, О. Савченко, Т. Сорокіна, І. Шванцара та ін.).

Отже, готовність дитини до опанування у школі навичками читання та письма на рідній мові залежатиме від стану її усного мовлення, сформованості функціональної та операціональної бази - способів дій, які є підгрунтям для набуття нових знань, умінь, навичок (Ш. Амонашвілі, А. Богуш, В. Давидов, Д. Ельконін, О. Запорожець, В. Лозова, О. Проскура, В. Тарасун та ін.).

Щодо загальної діагностики готовності дітей до вивчення іноземної мови, то її можна здійснювати з урахуванням передумов і показників, кореляція яких зазначена у Таблиці 1.

Як видно із Таблиці 1, кожний показник виокремлено на фоні певної передумови готовності дитини до вивчення іноземної мови. Низький показник за якимось параметром може свідчити про відсутність відповідної передумови і проявлятися у вигляді труднощів не лише під час навчання іноземної мови, а часто й при засвоєнні навичок читання та письма на рідній мові, при побудові учнем зв'язного висловлення тощо.

Таким чином, стійкі та специфічні помилки у процесі читання та письма можуть бути пов'язані з недоліками усного мовлення, з парціальною несформованістю в неї низки невербальних функцій, а саме: слухового гнозису, фонематичних процесів; навичок фонологічного аналізу і синтезу; з недорозвиненням лексикограматичної сторони мовлення, недостатньою сформованістю морфологічних і синтаксичних узагальнень; зниженням обсягу уваги та її концентрації; недостатнім розвитком зорового сприймання, аналізу та синтезу, зорово-просторових уявлень; недосконалістю зорово-просторової координації, кінестетичного контролю рухів; 
недостатнім розвитком мнестичних і мисленнєвих процесів; низькими показниками працездатності; слабкістю функції довільної саморегуляції; порушеннями моторної сфери (різного характеру та ступеню). Труднощі опанування іноземною мовою можуть бути обумовлені недоліками усної та писемної форм рідного мовлення, недостатньою сформованістю гнозису, праксису, мнестичних і мисленнєвих функцій.

Таблиця 1

\section{Кореляція умов і показників готовності молодших школярів до вивчення іноземної мови}

\begin{tabular}{|c|c|}
\hline $\begin{array}{l}\text { Передумови готовності дитини до вивчення } \\
\text { іноземної мови у початковій школі }\end{array}$ & $\begin{array}{c}\text { Показники готовності до оволодіння іноземною мовою } \\
\text { у початковій школі }\end{array}$ \\
\hline $\begin{array}{l}\text { Високий / достатній рівень загального } \\
\text { психофізіологічного розвитку (має вміння } \\
\text { усвідомлено спостерігати, зіставляти, обирати, } \\
\text { робити елементарний аналіз, здійснювати } \\
\text { елементарну творчу діяльність, орієнтуватися у } \\
\text { просторі та здійснювати сенсомоторні дії, необхідні } \\
\text { для виконання конкретних завдань, соціалізуватися) }\end{array}$ & $\begin{array}{l}\text { Наявність достатнього рівня допитливості, пізнавальної } \\
\text { і соціальної активності: дитина проявляє зацікавленість, } \\
\text { вимовляючи іноземні слова, називаючи предмети і явища } \\
\text { іноземною мовою, із задоволенням відповідає на прості } \\
\text { вербальні стимули іноземною мовою (вітання, прощання, } \\
\text { називання свого імені тощо). }\end{array}$ \\
\hline $\begin{array}{l}\text { Розвиненість емоційно-вольової і мотиваційної } \\
\text { сфер (проявляє здатність дотримуватися соціально } \\
\text { прийнятої поведінки, домовлятися, виконувати } \\
\text { інструкції; проявляє допитливість) }\end{array}$ & $\begin{array}{l}\text { Здатність до співпраці з учителем і однокласниками: } \\
\text { дитина виконує прості інструкції іноземною мовою типу } \\
\text { "Read! Читай!’Look at the picture! Дивись на картинку!” } \\
\text { тощо, залучається до виконання спільних завдань } 3 \\
\text { однокласниками, таких як питально-відповідна форма } \\
\text { роботи, навчальні ігри, змагання. }\end{array}$ \\
\hline Розвиненість фонематичного слуху & $\begin{array}{l}\text { Наявність високих імітативних здібностей: дитина легко і } \\
\text { точно повторює як окремі іншомовні звуки, так і цілі слова } \\
\text { без видимих зусиль і додаткових пояснень. }\end{array}$ \\
\hline $\begin{array}{l}\text { Наявність здібностей до лексико-граматичних } \\
\text { узагальнень }\end{array}$ & $\begin{array}{l}\text { Спроможність до швидкого запам'ятовування назв } \\
\text { конкретних речей: дитина запам'ятовує назви 5-7 } \\
\text { предметів після 1-3 пред'явлень. }\end{array}$ \\
\hline $\begin{array}{l}\text { Володіння граматикою рідної мови на практичному } \\
\text { рівні }\end{array}$ & $\begin{array}{l}\text { Спроможність коректно зіставляти окремі речення з } \\
\text { іхньою комунікативною функцією: дитина правильно } \\
\text { відповідає англійською мовою на вітання, прощання, } \\
\text { прості запитання про себе. }\end{array}$ \\
\hline $\begin{array}{l}\text { Достатня розвиненість дрібної моторики і зорового } \\
\text { гнозису }\end{array}$ & $\begin{array}{l}\text { Наявність здібностей до формування графічних навичок } \\
\text { в іноземній мові: дитина розпізнає букви іноземного } \\
\text { алфавіту, запам'ятовує назви 3-5 літер за 1-3 } \\
\text { пред'явлення, правильно копіює літери, може іх написати } \\
\text { напам'ять після того, як пропише 1-2 рядки кожної літери. }\end{array}$ \\
\hline
\end{tabular}

Зважаючи на вищевказане, при підготовці дитини до школи необхідно цілеспрямовано формувати в неї всі сторони мовленнєвої системи: увагу, різні види сприймання, пам'яті, мислення, уяви; позитивну мотивацію до навчання; передумови навчальної діяльності; лінгвістичні здібності; пізнавальну активність і самостійність.

Висновки і перспективи подальших досліджень. Отже, у початковій школі дитина оволодіває писемною формою рідної мови, яка потребує достатньої сформованості усного мовлення, цілої низки невербальних функцій, відповідної мотивації. Недоліки усного мовлення та труднощі засвоєння навичок читання та письма на рідній мові корелюють із труднощами опанування молодшими школярами іноземною мовою. Зважаючи на це, доцільною є своєчасна діагностика та виявлення дітей із низькими показниками сформованості тих функцій, від яких залежить успішне опанування ними предметами мовного циклу.

У подальшому плануємо проведення діагностичних заходів для виявлення відсотку дітей із труднощами засвоєння у початковій школі писемної форми рідної мови та англійської мови як іноземної.

1. Выготский Л. С. Лекции по психологии / Л. С. Выготский. - Собр. соч.: в 6 т. - Т.2. - М.: Педагогика, 1982. - С. 300.

2. Голуб Н. М. Корекція порушень писемного мовлення в дітей молодшого шкільного віку: монографія / Н. М. Голуб. - Харків : Майдан, 2014. - 366 с.

\section{Reference}

1. Vyigotskiy L. S. Lektsii po psihologii / L. S. Vyigotskiy. - Sobr. soch.:v 6 t. - T.2. - M.: Pedagogika, 1982. - S. 300.

2. Golub N. M. Korektsiia porushen pysemnoho movlennia v ditei molodshoho shkilnoho viku: monohrafiia / N. M. Golub. - Kharkiv : Maidan, 2014. - $366 \mathrm{~s}$. 